\title{
IAMJ
}

INTERNATIONAL

AYURVEDIC

MEDICAL JOURNAL

ISSN: 2320-5091

Impact Factor: 6.719

\section{ROLE OF VIRECHANA IN THE MANAGEMENT OF INDRALUPTA - A SINGLE CASE REPORT}

\section{Harikrishnan. N. Menon ${ }^{1}$, Syed Munawar Pasha²}

${ }^{1}$ PG Scholar, Department of PG Studies in Shalakya Tantra, Government Ayurveda Medical College, Bengaluru-560009, Karnataka, India

${ }^{2}$ Associate Professor \& H.O.D, Department of PG Studies in Shalakya Tantra, Government Ayurveda Medical College, Bengaluru-560009, Karnataka, India

Corresponding Author: drhariknmenon@gmail.com

https://doi.org/10.46607/iamj5009082021

(Published Online: August 2021)

Open Access

(C) International Ayurvedic Medical Journal, India 2021

Article Received: 30/07//2021 - Peer Reviewed: 13/08/2021 - Accepted for Publication: 14/08/2021

\section{Check for updates}

\section{ABSTRACT}

Introduction: Indralupta is a type of Kapalagata Roga, it occurs when Pitta along with Vata affecting the hair follicles to become thin and fall, later on, due to vitiation of Kapha and Rakta it blocks the regrowth of hairs. It can be correlated to Alopecia. Alopecia areata is one of its types and it is also known as spot baldness. It may be regarded as immune-mediated hair loss and it is the commonest cause of patchy hair loss.

Materials and methods: A 20-year-old female patient approached Shalakya Tantra OPD of SJIIM, Bengaluru complaining of patchy hair loss in the parietal region for 6 months, the subject was systemically reviewed and diagnosed as alopecia areata, were administered with Snehapana, Virechana, internal medication and lepa for 2 months. Result: The subject showed marked improvement in assessment criteria's as we can see in the photographs taken in the different stages of the treatment.

Discussion: Usually Indralupta is treated with more bahya Prayogas like prachanna, here in this study we have concentrated more on the root cause of the disease and treating the underlying cause by Internal medications, thus we got a positive result for the same. 
Keywords: Alopecia areata, Indralupta, Virechana, Ayurveda.

\section{INTRODUCTION}

Alopecia areata is a common autoimmune disorder that often results in unpredictable hair loss. In the majority of cases, hair falls out in small patches around the size of a quarter. For most people, hair loss is nothing more than a few patches, though in some cases it can be more extreme. Sometimes it can lead to the complete loss of hair on the scalp, which is known as alopecia totalis, or in extreme cases, the entire body is affected, which is known as alopecia universalis ${ }^{1}$.

It affects $0.1 \%$ to $0.2 \%$ of the population and occurs in both males and females. There are no subjective symptoms, and the denuded area of the scalp is of normal colour and texture. A history of acute emotional stress or anxiety preceding the onset is a common cause for the worsening of the condition ${ }^{2}$. Alopecia areata does not directly make people sick, nor is it contagious. However, it can be difficult to adapt to it emotionally. For many people, alopecia areata is a traumatic disease that warrants treatment addressing the emotional aspect of hair loss, as well as the hair loss itself.

In the conventional system of medicine, Alopecia is treated by using corticosteroids and various immunosuppressants in the form of injections and ointments ${ }^{3}$, which is not ideal in the present scenario of the pandemic, suppressing the immune system will make the individual more prone to mucormycosis like condition. Thus, Ayurveda can play a crucial role in the treatment of Alopecia areata.

\section{MATERIALS \& METHODS}

Case Report:- A female patient of age 22 years approached Shalakya OPD of SJIIM hospital, Bengaluru on 30.5.2020, complaining of patchy hair loss on the left parietal region for 6 months.

History of present illness:-The subject was normal before 6 months gradually she observed falling of hair in a quarter pattern in the parietal region, she underwent treatment for the same in modern medicine and got relief, but in the past 1 month again there was reoccurrence and she consulted our OPD for Ayurvedic treatment.

History of past illness:- The subject was diagnosed with polycystic ovary syndrome 2 years ago and is undergoing Ayurvedic treatment for the same. Because of that, she is having abnormal menstruation.

\section{Personal History:}

- Diet: Mixed, more intake of fried and salty food.

- Vihara:- taking food at an improper time and sleeping late at night.

Family History: - nothing specific

\section{Examination}

\section{Ashta sthana pareeksha}

1. Nadi: $72 / \mathrm{min}$

2. Mutra: 4-6 times/ day

3. Mala: once/day

4. Jihwa: Coated

5. Shabda: Prakrutha

6. Sparsha: Snigdha

7. Drik: Prakrutha

8. Akruti: Madhyama

$>$ Systemic Examination: The respiratory system, Cardiovascular system, Gastro-Intestinal system, Central nervous system, the musculoskeletal system has shown no abnormality.

$>$ Local examination: Disease-specific scalp examination of the scalp is as shown in table 1 .

\section{$>$ Investigation}

CBC- normal limits

Clotting time- $8 \mathrm{~min}$

Bleeding time- $3 \mathrm{~min}$

RBS- $118 \mathrm{mg} / \mathrm{dl}$

PREATMENT: The treatment adopted is as shown in Table 2.

RESULT: There was an improvement of the condition as shown in fig. 1, fig 2, fig 3, Showing before the treatment, during the treatment and after the treatment respectively and during the follow up after one month there were no signs of re-occurrence. 


\section{DISCUSSION}

Karthikacharya has told that in females' incidence of Indralupta will be less because the vitiated Rakta is eliminated through Raja srava ${ }^{4}$, in this study we can see that the subject had abnormal menstruation due to PCOS. So here we have tried to concentrate on treating the root cause of the disease. Thus, we had administered Classical virechana, by giving Snehapana with Maha thikthaka ghruta which does Pitha vata hara action and followed by Virechana with trivrit lehya. Virechana does the Vata pitha hara action, it normalises the vimargagamana of Vata ${ }^{5}$. Thus, the menstruation after 1 month became normal and dooshitha rakta and pitha were eliminated.

- Gandhaka vati: act as anti-fungal and purifies the blood, also sulphur promotes hair growth ${ }^{6}$.

- Saptamrutha loha: it acts as an antioxidative and immunomodulator.

- Ashokarishta: is indicated in asrugdhara, normalises the menstrual cycle ${ }^{7}$.

- Lepa: trikatu churna and nimbu swarasa, is having ushna, theekshna property it removes the blockage of hair follicles due to Kapha dosha ${ }^{8}$.

\section{CONCLUSION}

Thus, Alopecia areata can be treated in Ayurveda successfully, it is cost-effective, and drugs are easily available. As of such, there are no complications observed. Along with the treatment, lifestyle and food habits have also an equal role in recovery. Thus, we had advised Pathya and Apathya during the treatment and in follow up. Alopecia is such a disease that affects the emotional and mental well being of an individual, thus early treatment and guidance with the help of Ayurveda can prevent its advance and its further reoccurrence.

\section{REFERENCES}

1. Jacquelyn Cafasso. Reviewed by Alana Biggers. Healthline Publishers. July 30, 2019. https://www.healthline.com/health/alopecia-areata

2. Jitendar Kumar, Prashanth Dharmarajan.A case study on Ayurvedic management of Alopecia areata (Khalitya). Anveshana Ayurveda Medical Journal. Volume 3. Issue 2. Mar-Apr 2017.pp.1293-1297.

3. James Mcintosh. What's to know about Alopecia areata. The University of Illinois.Medical News today. The USA. Dec 22.2017. https://www.medicalnewstoday.com/articles/70956

4. Dingari Lakshmana chary. The Shalakya Tantra Disease of Eye Head \& E.N.T. Chaukambha Sanskrit Prathishthan. Delhi. Edition 2005. pp.28.

5. Vagbhata. Ashtanga Hridaya. Kalpa Sthana. (2/9). Aruna Datta. Reprint 2010. Chaukambha Subharati Prakashan. Varanasi. Pp 813

6. Vaidya Laksmipati sastri. Yogaratnakara with Vidyotini Hindi commentary. Edited by Bhisagratna Brahma Sankar Sastri. Varanasi: Chaukambha Praakashan: 2012.Rasayana adhikara. pp 344.

7. Govind Das Sen. Bhaishajya Ratnavali. Stree roga. (114-116). Varanasi. Chaukambha Subharati Prakashan. 1997.pp 605.

8. Soundarya N, Rathis S. Role of Jaloukavacharana in the management of Cicatricle Alopecia- A case report. Journal of Ayurveda and Integrated medical sciences. Vol 5. Issue 6. Nov-Dec 2020.pp351-355.

\section{TABLES}

Table 1: Examination of scalp

\begin{tabular}{|l|l|}
\hline Parameters & Findings \\
\hline Site of hair loss scalp & Left parietal region \\
\hline Number of patches & One \\
\hline Size of the patch & $6 \mathrm{~cm}$ length, 4cm width \\
\hline The skin on the patch & No scar or inflammation present \\
\hline
\end{tabular}


Table 2: Treatment

\begin{tabular}{|c|c|c|c|}
\hline Treatment & Medicine & Dose & Duration \\
\hline Snehapana & Maha thikthaka grutha & $\begin{array}{l}20 \mathrm{ml}, 30 \mathrm{ml} .50 \mathrm{ml}, 70 \mathrm{ml}, 90 \mathrm{ml}, 110 \mathrm{ml} .130 \mathrm{ml} \\
\text { (The dose is increased every day) }\end{array}$ & For 7 days \\
\hline Svedana \& abhyanga & & & On $8^{\text {th }}$ day \\
\hline Virechana & Trivrit lehya & $45 \mathrm{gm}$ & 1day (16 vegas) \\
\hline Samsarjana krama & $\begin{array}{l}\text { Peya } \\
\text { Vilepi } \\
\text { yusha }\end{array}$ & & 9th-13th day \\
\hline Internally & $\begin{array}{l}\text { a) Gandhaka rasayana } \\
\text { b) Saptamrutha loha } \\
\text { c) Avipathikara churna as } \\
\text { nitya virechana } \\
\text { d) Ashokarishta }\end{array}$ & $\begin{array}{l}2-0-2(\mathrm{a} / \mathrm{f}) \\
0-0-2(\mathrm{a} / \mathrm{f}) \\
0-0-1 \quad \mathrm{Tsp}(\mathrm{a} / \mathrm{f}) \\
0-20 \mathrm{ml}-0(\mathrm{a} / \mathrm{f})\end{array}$ & $\begin{array}{l}14^{\text {th }}-60^{\text {th }} \text { day } \\
\text { From } 20^{\text {th }} \text { day to } 27^{\text {th }} \\
\text { day } \\
\text { From } 28^{\text {th }} \text { day to } 60^{\text {th }} \\
\text { day }\end{array}$ \\
\hline Externally & Application of trikatu churna & $\begin{array}{l}\text { Over the affected area } \\
\text { For } 3 \text { weeks since the } 30^{\text {th }} \text { day }\end{array}$ & \\
\hline
\end{tabular}

\section{FIGURES}

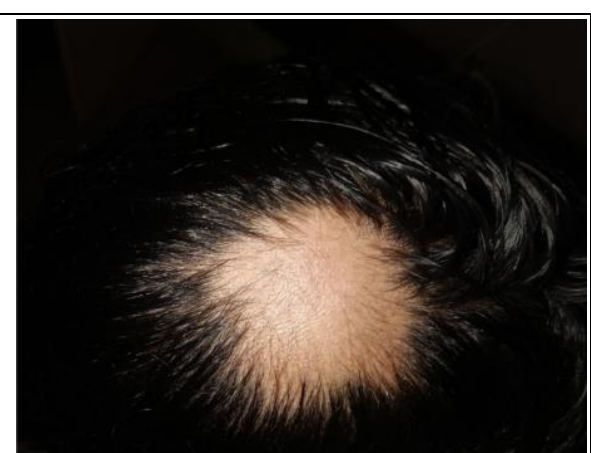

Fig.1. Before treatment

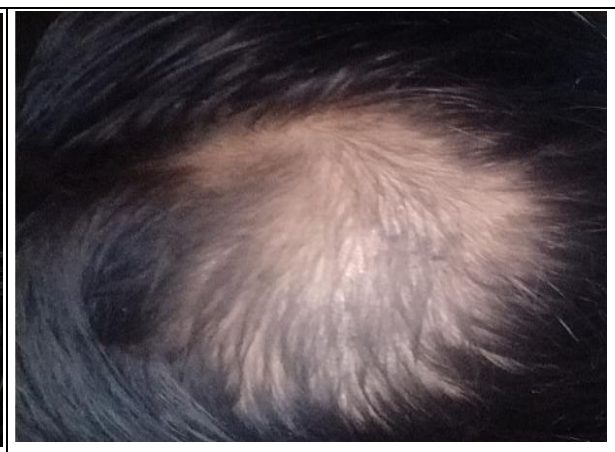

Fig.2. During treatment

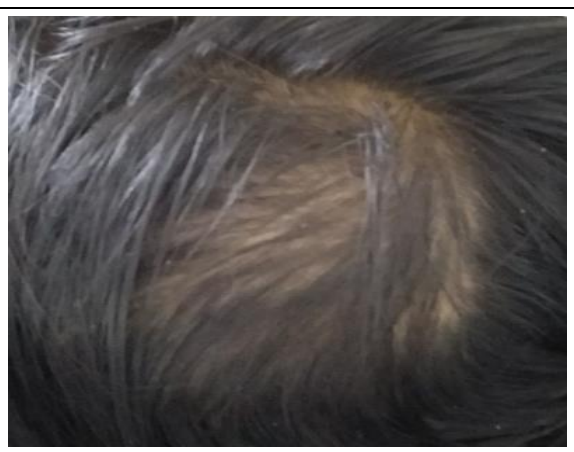

Fig,3. After treatment

\section{Source of Support: Nil}

\section{Conflict of Interest: None Declared}

How to cite this URL: Harikrishnan. $\mathcal{N}$. Menon oL Syed Munawar Pasha: Role Of Virechana In The Management Of Indralupta - $\mathcal{A}$ Single Case Report. International Ayurvedic Medical Journal \{online\} 2021 \{cited August 2021\} Available from: http://www.iamj.in/posts/images/upload/1913 1916.pdf 